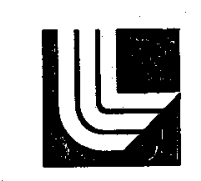

LAWRENCE LIVERMORE LABORATORY

University of California/Livermore, California/ 94550

UCRL-52640

\title{
STUDIES OF BRINE CHEMISTRY, PRECIPITATION OF SOLIDS, AND SCALE FORMATION AT THE SALTON SEA GEOTHERMAL FIELD
}

J.E. Harrar

C.H. Otto, Jr.

S.B. Deutscher

R.W. Ryon

G.E. Tardiff

MS. date: January 8, 1979 


\section{DISCLAIMER}

This report was prepared as an account of work sponsored by an agency of the United States Government. Neither the United States Government nor any agency Thereof, nor any of their employees, makes any warranty, express or implied, or assumes any legal liability or responsibility for the accuracy, completeness, or usefulness of any information, apparatus, product, or process disclosed, or represents that its use would not infringe privately owned rights. Reference herein to any specific commercial product, process, or service by trade name, trademark, manufacturer, or otherwise does not necessarily constitute or imply its endorsement, recommendation, or favoring by the United States Government or any agency thereof. The views and opinions of authors expressed herein do not necessarily state or reflect those of the United States Government or any agency thereof. 


\section{DISCLAIMER}

Portions of this document may be illegible in electronic image products. Images are produced from the best available original document. 


\section{CONTENTS}

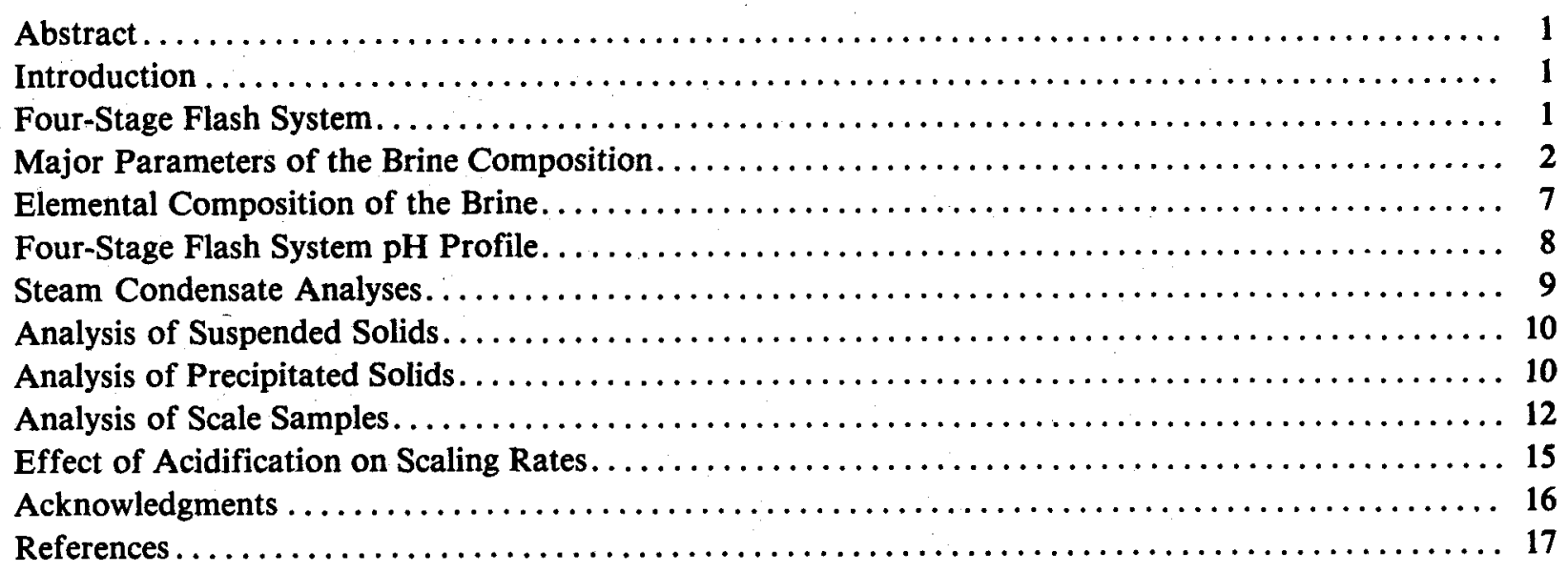




\title{
STUDIES OF BRINE CHEMISTRY, PRECIPITATION OF SOLIDS, AND SCALE FORMATION AT THE SALTON SEA GEOTHERMAL FIELD
}

\begin{abstract}
We investigated factors affecting the precipitation of solids and deposition of scale from the hypersaline brines of the Salton Sea geothermal field-two potential problems in the proposed utilization of these brines for electric power generation. We determined the average physical and chemical composition of the fluid from Magmamax No. 1 well and noted the effects of changes in well flow rate on the chemistry of the brine and the formation of solids. We also studied the effects of $\mathrm{pH}$ on the process stream chemistry and on the composition and rates of formation of solids and scale that precipitated from this brine. Reduction of the $\mathrm{pH}$ from 6 to 4-5 decreased the scaling rates and increased the proportions of barium sulfate and calcium fluoride in the scales and precipitated solids. These studies were conducted using a small-scale four-stage brine flash system constructed at the site.
\end{abstract}

\section{INTRODUCTION}

Several important potential problems in the utilization of the hypersaline brines of the Imperial Valley for electric power generation are under investigation by the Lawrence Livermore Laboratory (LLL). One is the development of techniques for minimizing or controlling the precipitation of solids and deposition of scale from the brine as it cools. Another is the selection of materials that resist corrosion and erosion by the hot, highly saline brine. Progress in these and other areas, including brine disposal, energy conversion technology design studies, and geological investigations, has been reported. $1-7$

In the summer of 1977 , a small-scale (6 gpm) four-stage brine flash system was constructed at the
Niland test site; brine was supplied from Magmamax No. 1 well. The system was used to determine the effect of modest $\mathrm{pH}$ reduction on scaling rates, materials response, the chemistry of the process streams, and the composition of suspended solids and scales. The effluent brine was also used in a series of off-line bench tests of organic additives for scale $\operatorname{control}^{3}$ and to measure baseline rates of precipitation of solids. During this time, a number of analyses of the geothermal fluids (with and without acidification) and solids were carried out, and these are reported here. Preliminary reports of the results have already appeared, $2-6$ and others will be forthcoming. 7

\section{FOUR-STAGE FLASH SYSTEM}

A simplified diagram of the LLL Four-Stage Flash System is shown in Fig. 1. In addition to the brine sampling ports shown, there were also ports in the brine bypass for sampling brine and steam from the first-stage separator and ports for sampling steam from the second-and third-stage flash tanks.
Each of these ports was connected to a stainlesssteel or zirconium cooling/coil for cooling the samples to ambient temperature.

Also not shown in Fig. 1 is apparatus connected at various times to the experiment station. This included a section of large-diameter pipe 


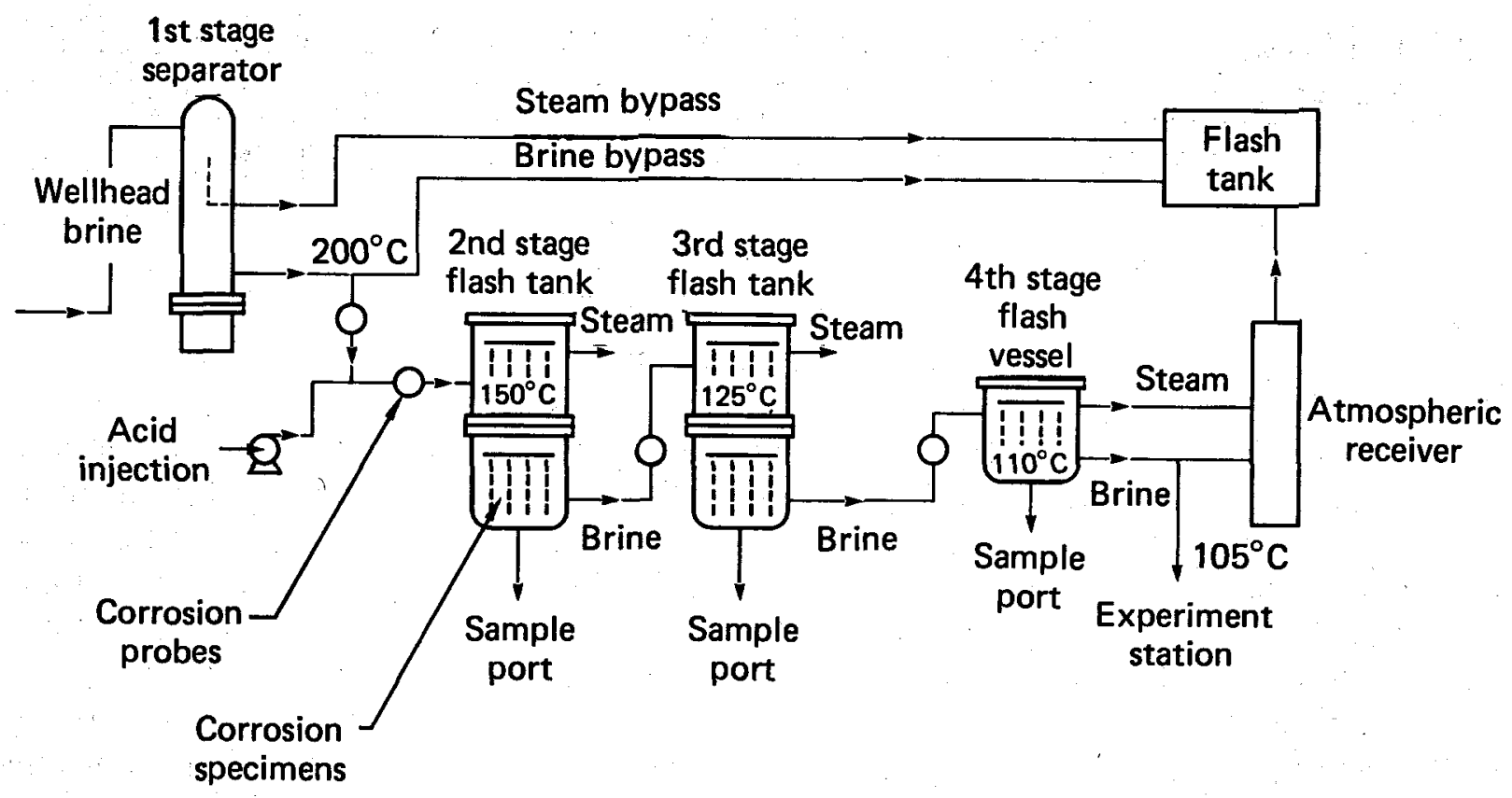

Fig. 1. The LLL geothermal four-stage flash system.

through which a portion of the brine flowed. The effect of this "delay line" was to "age" the brine an additional 20 minutes to simulate the residence time of brine in the injection line of the San Diego Gas and Electric Company Geothermal Loop Experimental Facility (GLEF). A slotted metal cylinder was connected to the delay line to simulate the slotted liners in the completion interval of the injection well. Apparatus for core flooding experiments and additional corrosion-measurement equipment were also connected at various times to the experiment station.

\section{MAJOR PARAMETERS OF THE BRINE COMPOSITION}

The LLL four-stage flash system was first operated intermittently from August to November 1977. Baseline data on the precipitation of solids (largely silica) from the effluent brine as a function of $\mathrm{pH}$ were obtained. ${ }^{6}$ During this time, measurements were also made to determine the optimum $\mathrm{pH}$ for the 30-day corrosion test, and the first tests of organic additives for scale control ${ }^{3}$ were carried out. It became evident during this period that the composition of the brine changed considerably with the flow rate of the well. It was observed that the composition of the fourth-stage effluent brine that we usually monitored changed markedly, depending upon whether or not the GLEF was also drawing fluid from the well (Tables 1-3). Full flow of Magmamax No. 1 to the GLEF
Table 1. Total dissolved solids in Magmamax No. 1 effluent brine $\left(105^{\circ} \mathrm{C}, 1 \mathrm{~atm}\right)$.

\begin{tabular}{|c|c|c|c|}
\hline Date & $\begin{array}{c}\text { Density at } 25^{\circ} \mathrm{C}, \\
\mathrm{g} / \mathrm{cm}^{3}\end{array}$ & $\begin{array}{c}\text { Total dissolved } \\
\text { solids, wt\% }\end{array}$ & $\begin{array}{l}\text { GLEF in } \\
\text { operation }\end{array}$ \\
\hline \multicolumn{4}{|l|}{1977} \\
\hline Sept. 17 & 1.141 & 19.0 & No \\
\hline Sept. 19 & 1.145 & 19.9 & No \\
\hline Sept. 21 & 1.143 & 19.4 & No \\
\hline Sept. 22 & 1.172 & 22.5 & Yes \\
\hline Oct. 23 & 1.149 & 21.2 & No \\
\hline Dec. 5 & 1.142 & 19.7 & No \\
\hline Dec. 14 & 1.174 & 22.7 & Yes \\
\hline \multicolumn{4}{|l|}{1978} \\
\hline Feb. 3 & 1.170 & 22.4 & $\cdots$ \\
\hline Feb. 3 (Third stage) & & 21.3 & \\
\hline Feb. 3 (Second stage) & & 20.3 & \\
\hline Feb. 3 (First stage) & & 19.1 & \\
\hline
\end{tabular}

${ }^{a}$ See Table 2. 
Table 2. Gross composition of effluent brine sampled directly at fourth stage at $105^{\circ} \mathrm{C}$ during the 700 -hour corrosion and scaling test.

\begin{tabular}{|c|c|c|c|c|c|c|}
\hline Date & Time & $\mathbf{p H}$ & $\begin{array}{c}\text { Chloride, } \\
M\end{array}$ & $\begin{array}{c}\text { Density at } \\
25^{\circ} \mathrm{C}, \\
\mathrm{g} / \mathrm{cm}^{3}\end{array}$ & $\begin{array}{l}\text { Initial } \\
\mathrm{SiO}_{2}, \\
\mathbf{m g} / \mathbf{k g}\end{array}$ & $\begin{array}{l}\text { GLEF in } \\
\text { operation }\end{array}$ \\
\hline Dec. 4,1977 & 1440 & 6.00 & 3.68 & & 464 & No \\
\hline Dec. 5 & 1130 & 6.00 & 3.78 & 1.142 & 450 & No \\
\hline Dec. 6 & 1030 & 5.45 & & & 450 & No \\
\hline Dec. 6 & 1345 & 5.00 & 4.06 & & & No \\
\hline Dec. 7 & 1445 & 5.08 & 4.20 & & 502 & No \\
\hline Dec. 8 & 0910 & 4.53 & 4.60 & & 595 & Yes \\
\hline Dec. 8 & 1600 & 5.02 & 4.50 & & & Yes \\
\hline Dec. 9 & 0920 & & & & 540 & Yes \\
\hline Dec. 9 & 1030 & 4.83 & 4.05 & & & Yes \\
\hline Dec. 9 & 1600 & 4.65 & 4.38 & & & Yes \\
\hline Dec. 10 & 0700 & 4.37 & 4.41 & & & Yes \\
\hline Dec. 13 & 1400 & & & & 558 & Yes \\
\hline Dec. 13 & 1700 & & 4.44 & & & Yes \\
\hline Dec. 14 & 0915 & 4.92 & & & $437^{2}$ & Yes \\
\hline Dec. 14 & 1100 & 4.85 & 4.46 & 1.174 & 562 & Yes \\
\hline Jan. 19, 1978 & 1000 & 3.94 & & & & No \\
\hline Jan. 19 & 1345 & & 3.13 & & & Na \\
\hline Jan. 19 & 1530 & 4.42 & & 1.131 & 444 & No \\
\hline Jan. 20 & 0900 & 4.20 & 3.26 & 1.131 & 444 & No \\
\hline Jan. 20 & 1430 & & 3.36 & & & No \\
\hline Jan. 21 & 0900 & & 3.55 & & 420 & No \\
\hline Jan. 22 & 1430 & 4.34 & 4.16 & 1.164 & 489 & Yes \\
\hline Jan. 23 & 1400 & 4.77 & 4.06 & 1.161 & $\mathbf{5 0 7}$ & Yes \\
\hline Jan. $24^{b}$ & 1400 & 5.00 & 3.63 & 1.149 & 515 & Yes \\
\hline Jan. 25 & 0745 & 3.51 & 4,02 & & & Yes \\
\hline Jan. 25 & 1000 & 3.48 & & 1.158 & 490 & Yes \\
\hline Jan. 25 & 1400 & 3.65 & 4.14 & 1.163 & & Yes \\
\hline Jan. 26 & Plant & & & & & No \\
\hline Jan. 27 & 1640 & 4.38 & 3.75 & 1.148 & 515 & No \\
\hline Jan. 28 & 1315 & 4.20 & 4.03 & 1.161 & 489 & Yes \\
\hline Jan. 29 & 1115 & 4.50 & 4.12 & 1.161 & 485 & Yes \\
\hline Jan. 30 & 1440 & 3.41 & 4.49 & 1.173 & 521 & Yes \\
\hline Jan. 31 & 0750 & & 4.48 & $\because$ & & Yes \\
\hline Jan. 31 & 0833 & 4.14 & 4.46 & 1.171 & 548 & Yes \\
\hline Feb. 1-2 & Plant & & & & & \\
\hline Feb. 3 & 1400 & 3.90 & 4.31 & $1.170^{c}$ & 548 & Nod \\
\hline Feb. 3 & 1700 & 4.09 & & 1.152 & & No \\
\hline Feb. 4 & 0830 & 4.52 & 3.91 & 1.160 & 526 & No \\
\hline Feb. 4 & 1450 & 4.20 & 4.74 & $1.180^{e}$ & & Yes $f$ \\
\hline Feb. 4 & 1630 & & & 1.175 & 546 & Yes' \\
\hline Feb. 5 & 1600 & 3.82 & 4.27 & 1.172 & 546 & Yes \\
\hline Feb. 6 & 0900 & 4.03 & 4.40 & $1.172^{\mathrm{C}}$ & 566 & No $h$ \\
\hline Feb. 7 & 0820 & 3.92 & 4.14 & 1.160 & 522 & No \\
\hline Feb. 8 & 0900 & 4.16 & 4.05 & 1.158 & 517 & No \\
\hline Feb. 8 & 1615 & 3.75 & 4.27 & 1.169 & $\therefore$ & No \\
\hline Feb. 9 & 1127 & 3.70 & 4.04 & 1.167 & 528 & No \\
\hline Feb. 10 & 1100 & 3.75 & & 1.165 & 520 & No \\
\hline Feb. 12 & 1500 & & 3.95 & 1.158 & 462 & No \\
\hline Feb. 13 & 0815 & 4.08 & 3.77 & 1.159 & 511 & No \\
\hline
\end{tabular}

Acid off for 1 hour just prior to sampling.

bPoor pH control this day.

c'Strong" brine persisted for several hours.

dOff at 0900 .

Maximum observed chloride concentration and density.

On at 1300.

GUSBM operated sporadically from Feb. 4 to Feb. 10 .

hOff at 0700 . 
Table 3. Parameters of geothermal brine for statistical analysis.

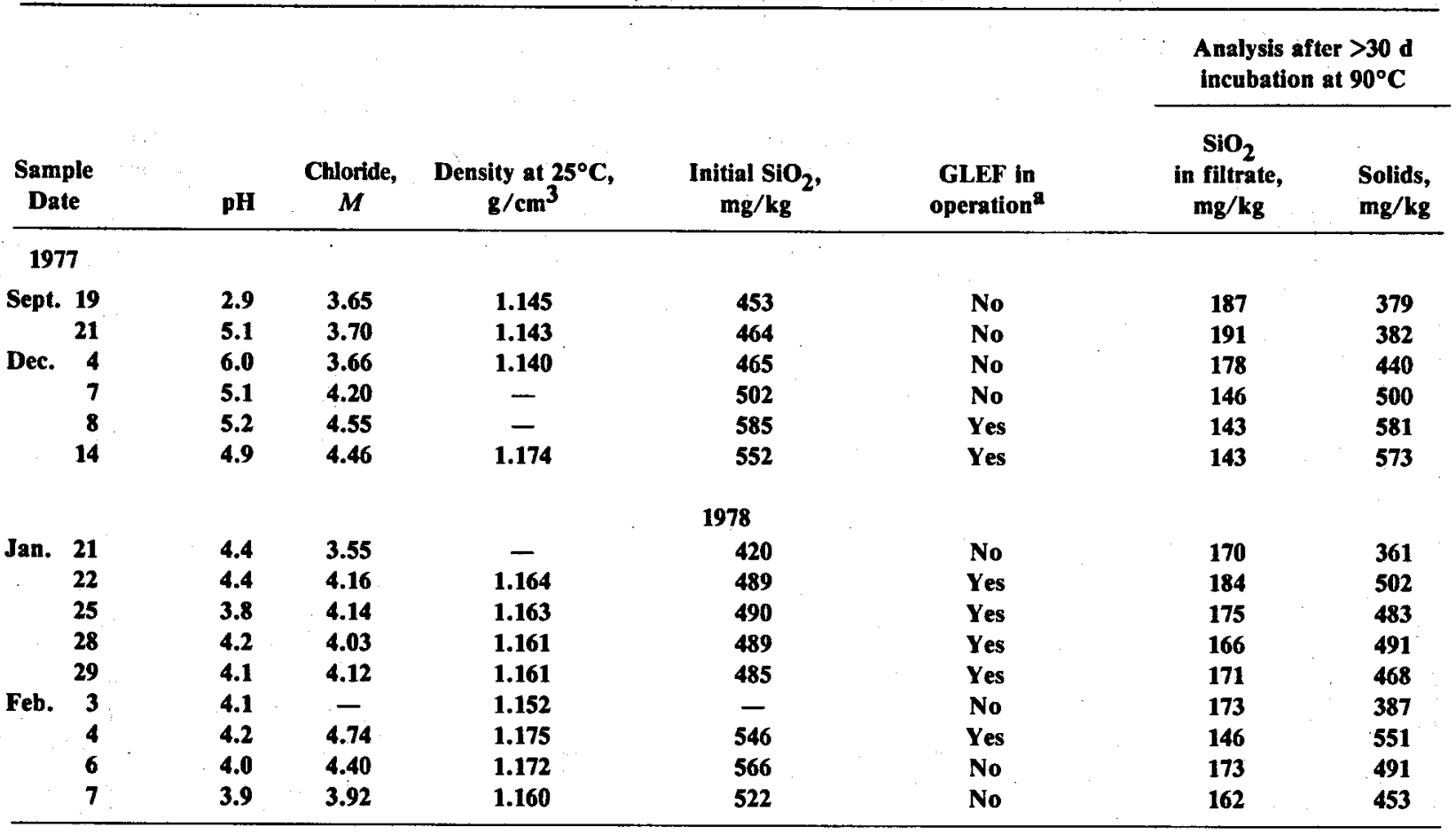

$a_{\text {No }}=0$, Yes $=1$ in statistical analysis.

was in the range of 300,000 to 400,000 pounds per hour whereas the flow capability of the LLL apparatus (including bypass) was only one-tenth of that amount.

Because of brine composition fluctuations, the effect of GLEF operation on fluid composition was monitored during the 30 -day (700-hour) corrosion test begun in December. The major parameters of the LLL system effluent brine are listed in Tables 1 and 2 with a notation on the status of the GLEF at the time the brine was sampled.

Some of the data in Table 1 are taken from an earlier report ${ }^{6}$; they show that total dissolved solids, chloride concentration, and density of the brine always increased with well flow rate. Except for the small amount of additional data given in Table 1, measurement of total dissolved solids was not performed after the initial shakedown tests of September 1977. The composition of the brine was more accurately indicated by its chloride concentration and density, and these measurements were faster to carry out.

Differences in the $\mathrm{pH}$ and concentrations of the major constituents of the brine affect solubil- ities and influence the rates of precipitation reactions that occur after the brine is flashed. This is illustrated in Fig. 2, which shows the rates of precipitation of silica and formation of suspended solids from brines having a low and a high concentration of chloride. At higher chloride (and total dissolved salt) concentrations, these rates are greater. The total quantity of solids produced once equilibrium has been attained is also larger for the "stronger" brines, as would be expected from the larger initial concentrations of dissolved silica. However, it also appears that at equilibrium the solubility of silica is lower for the stronger brines.

The relationship between the major parameters of the brines and the rates of solids and silica precipitation was examined in more detail by carrying out a statistical analysis of the various factors involved. Table 3 lists the composition of a series of brine samples taken during the four-stage flash system tests and the results of the determinations of the levels of suspended solids and dissolved silica after long-term ( $>30 \mathrm{~d}$ ) incubation 6 of the brines at $90^{\circ} \mathrm{C}$. The effect of GLEF operation was assessed by giving "no" a value of 0 and "yes". a value of 1 in the statistical matrix. 

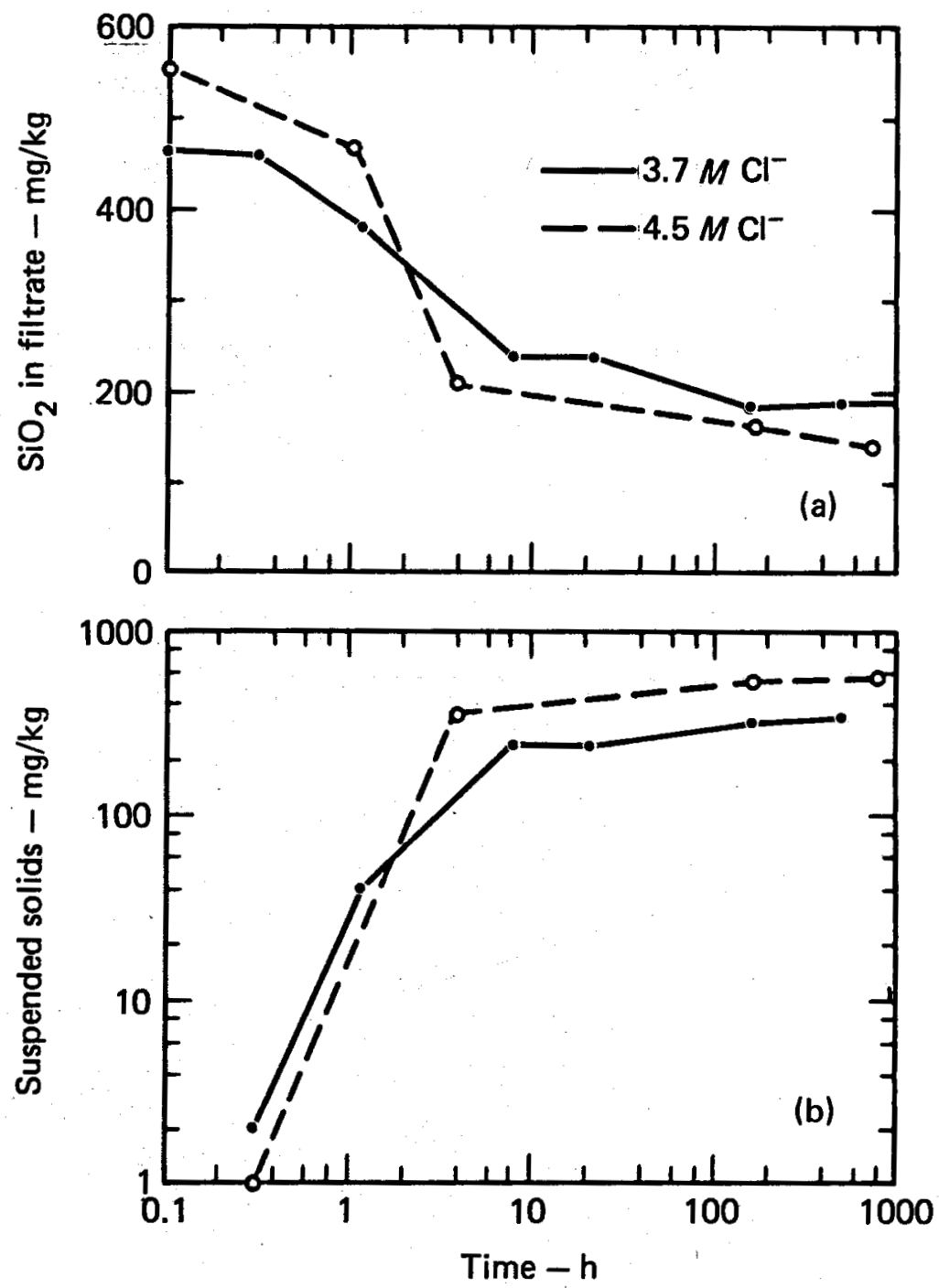

FIG. 2. (a) Concentrations of dissolved silica in filtrate and (b) concentration of filterable solids in brine (pH 5.0) as functions of time after flashing to $105^{\circ} \mathrm{C}$.

The results of a correlation analysis (Table 4) show that GLEF operation and its greater well flow rates increased the density, chloride concentration, and amount of long-term suspended solids of the brines. It is also significant, but not obvious from a cursory examination, that there was no correlation between the characteristics of the brine after incubation and the initial $\mathrm{pH}$ of the brine. There was a high positive correlation between the suspended solids and the initial $\mathrm{SiO}_{2}$. Another interesting result was the clear indication that the amount of
$\mathrm{SiO}_{2}$ in the filtrate, which is the equilibrium solubility of silica, was inversely proportional to the concentration of salts in the brine. This confirms the difference shown in Fig. 2a.

A plot of the solubility of silica as a function of the density of the brine and a linear least-squares fit to the data are given in Fig. 3. A value obtained for Magmamax No.2 well, which produces a stronger brine, is shown for comparison, and this value falls on the line fitted to the solubility data for brines taken from Magmamax No. 1 well. These data on 
Table 4. Estimated correlation matrix for the parameters of geothermal brine listed in Table 3.2

\begin{tabular}{|c|c|c|c|c|c|c|c|}
\hline & pH & $\begin{array}{c}\text { Chloride } \\
\text { concentration }\end{array}$ & Density & $\begin{array}{r}\text { Initial } \\
\mathrm{SiO}_{2}\end{array}$ & GLEF & $\underset{\text { filtrate }}{\mathrm{SiO}_{2} \text { in }}$ & Solids \\
\hline pH & 1.000 & 0.032 & -0.230 & 0.105 & $-\mathbf{0 . 0 3 2}$ & -0.268 & 0.255 \\
\hline Chloride concentration & & 1.000 & $0.951 *$ & $0.884^{\star}$ & $0.632^{\star}$ & $-0.709^{*}$ & $0.926 *$ \\
\hline Density & & & 1.000 & $0.872 *$ & $0.628^{*}$ & $-0.733^{*}$ & $0.875^{\star}$ \\
\hline Initial $\mathrm{SiO}_{2}$ & & & & 1.000 & 0.386 & $-0.669^{*}$ & $0.861 *$ \\
\hline GLEF & & & & & 1.000 & -0.366 & 0.718 * \\
\hline $\mathrm{SiO}_{2}$ in filtrate & & & & & & 1.000 & $-0.746^{*}$ \\
\hline Solids & & & & & & & 1.000 \\
\hline
\end{tabular}

$\mathbf{a}_{1.00}=$ perfect correlation; an asterisk indicates that the value is statistically different from zero at $\alpha=0.05$ level.

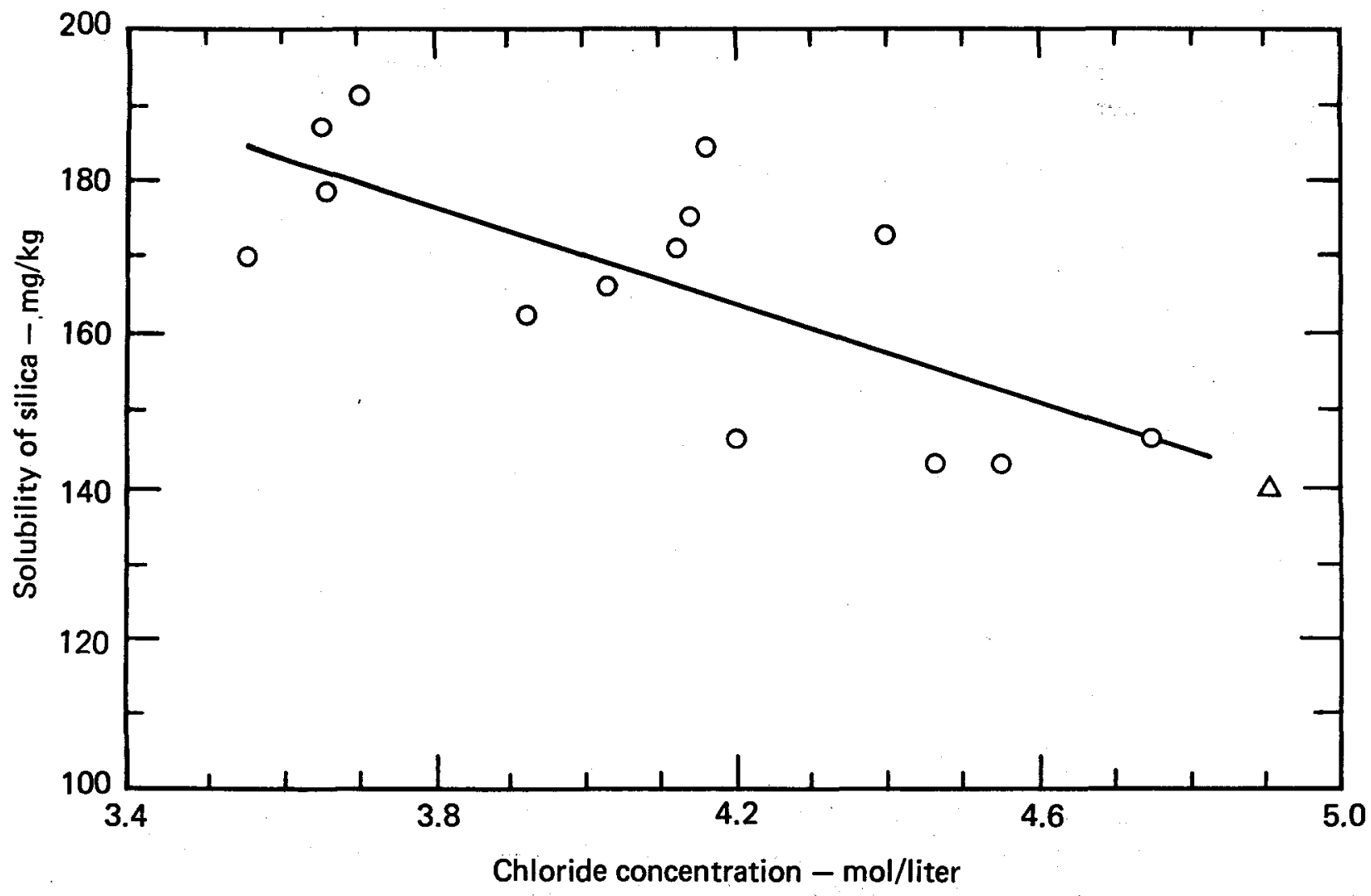

FIG. 3. Solubility of $\mathrm{SiO}_{2}$ as function of chloride concentration in Magmamax No. 1 brine at $90^{\circ} \mathrm{C}$. One value (triangle) obtained for Magmamax No. 2 is included for comparison, but it was not included in the curve-fitting calculations. Solubility of silica is given on a weight basis; to convert values to a volume basis, multiply the values by the brine density: 1.14 for low concentrations $(<4.3 \mathrm{~mol} / \mathrm{l})$ and 1.17 for high concentrations $(>4.3 \mathrm{~mol} / \mathrm{l})$. 
the effect of salt concentration on the solubility of silica extend to high concentrations the results obtained by investigators at EIC Corporation. ${ }^{8}$

These workers, who studied the chemistry of silica precipitation in a variety of simulated geothermal brines, also observed the dramatic accelerating effect of dissolved salts on the rate of precipitation of silica. The depressing effect of dissolved salt on the solubility of silica increases the rates of silica scaling from these brines ${ }^{3}$ and probably affects the accuracy of geothermometer temperature calculations. 9

The total salt concentration of the brine is reflected very accurately by its density, i.e., there is an almost perfect correlation between the density and the chloride concentration. Chloride concentrations, in turn, parallel the relative concentrations of most of the minor constituents of the brine (see below). Because the brine density is relatively easy to monitor on-line and in real time with suitable equipment, it appears to be a good parameter for process control.

The causes of the variation of brine composition with well flow rate in the manner observed is open to speculation. However, it appears reasonable that the temperature gradient that must exist downwell could also cause a gradient of increasing fluid salt concentration with depth and that increased well flow rates tap these more concentrated regions.

\section{ELEMENTAL COMPOSITION OF THE BRINE}

Three samples of the brine were taken for elemental analysis during the flash system tests. Samples of first-stage separated brine were taken on two different days to represent the two extremes of composition: when the GLEF was operating and when it was not. A sample of the effluent brine from the fourth stage also was taken shortly after sampling the first-stage brine on the day of GLEF operation. The brines were acidified to a concentration of $1 \% \mathrm{HCl}$ immediately upon sampling.

Historically, there are a number of elements that have always been determined in brines from the Salton Sea geothermal field. To ascertain whether unexpected ones were also present in the flash system samples, the two first-stage samples were evaporated to the solids, and these solids were analyzed by emission spectrography. The results of this analysis for the "less-common" elements are given in Table 5. As can be seen, the concentrations of most of these elements specifically sought are below the detection limits for the technique as indicated by "<" in Table 5. Silver and gallium lines were seen in the analysis, but the values given for these elements in Table 5 are somewhat uncertain and represent the maximum possible concentrations. For elements such as the platinum metals and uranium, the sensitivity of the technique was inadequate for a good analysis; the actual concentrations of these elements were probably two orders of magnitude below the detection limits shown in Table 5.
Table 5. Emission spectrographic analysis of solids from evaporation of first-stage separated brines from Magmamax No. 1.

\begin{tabular}{lcr}
\hline & $\begin{array}{c}\text { Estimated concentration in brine, mg/kg } \\
\text { Element }\end{array}$ & $\begin{array}{c}\text { Sampled } \\
\text { Jan. 31, 1978 }\end{array}$ \\
\cline { 2 - 3 } & $\begin{array}{c}\text { Sampled } \\
\text { Jan. 20, 1978 }\end{array}$ & \multicolumn{1}{c}{ so } \\
Al & 6 & 2 \\
V & 2 & 0.2 \\
Ga & 0.2 & 0.2 \\
Ag & 0.2 & $<0.2$ \\
Be, Cr & $<0.2$ & $<0.6$ \\
Bi, Co, Ni, Yb & $<0.6$ & $<2$ \\
Ti, Zr, In & $<2$ & $<2$ \\
Er, Eu, Tm & $<2$ & $<2$ \\
Y, Ge, Pd & $<2$ & $<6$ \\
Cd, Nb, Sb, Au & $<6$ & $<6$ \\
Dy, Gd, Ho, La & $<6$ & $<6$ \\
Lu, Nd, Pr, Sc & $<6$ & $<6$ \\
Ce, Tl & $<6$ & $<20$ \\
Pt, Rh, Ru & $<20$ & $<60$ \\
Sm, Tb, As, W & $<60$ & $<200$ \\
Th, U, Ta, Hi & $<200$ & \\
\hline
\end{tabular}

aOnly less-common elements are listed.

A more accurate determination of the most important elemental constituents of the brine was performed by atomic absorption spectrophotometry (AAS) using the method of standard addition. Iron was determined by the 1,10-phenanthroline spectrophotometric method. The brines were also 
analyzed by means of a computer-controlled, inductively-coupled-plasma (ICP) emission spectrometer system. A brief study of the accuracy of the ICP technique compared to AAS for these brines has been reported ${ }^{10}$; analysis by ICP requires a 20- to 50-fold dilution of the samples.

Table 6 summarizes the results of the analyses of the three geothermal brines. Comparing the two brines sampled at two stages of the plant on January 31 , one can see the increase in brine concentration as it was flashed from $\sim 200$ to $\sim 105^{\circ} \mathrm{C}$ and the steam removed. The concentrations of most of the constituents of the brine (except magnesium and strontium) were higher when the GLEF was operating on January 31 than on January 20 . Although boron was determined here only by the ICP technique, it appears to be an important constituent and should be included in the primary group for analysis in future work. In general, the levels of most of the elemental constituents found in the present work were similar to those previously reported for Salton Sea geothermal brines. 11,12

One element for which an accurate determination was not obtained is barium. The brines sampled during the flash tank tests had been acidified in the plant to $\mathrm{pH} \sim 4.5$ for the corrosion tests. Under these conditions, high concentrations of $\mathrm{BaSO}_{4}$ appeared in the low-temperature scales, and this compound also precipitated from the brines after they were sampled but before they were analyzed at Livermore. Thus the concentration of remaining soluble barium was significantly lower than that in the original brine.

This error was not discovered until after conclusion of the flash system tests. On July 21,1978 , during a later period of LLL plant operation (but not of GLEF operation), a new sample of first-stage brine was taken specifically for barium analysis. This sample was immediately diluted with water by a factor of seven, acidified to a concentration of $1 \% \mathrm{HCl}$, and analyzed by AAS within two days. The value found in this case was $290 \mathrm{mg} / \mathrm{kg}$ (compared to $\sim 90 \mathrm{mg} / \mathrm{kg}$ for the flash tank samples); thus Magmamax No. 1 brine probably had concen-
Table 6. Elemental analyses of geothermal brines from Magmamax No. 1.

\begin{tabular}{lccc}
\hline & $\begin{array}{c}\text { First stage } \\
\text { at 1115, } \\
\text { Jan. 20, 1978 }\end{array}$ & $\begin{array}{c}\text { Finst stage } \\
\text { at 0828, } \\
\text { Jan. 31, 1978 }\end{array}$ & $\begin{array}{c}\text { Fourth stage } \\
\text { at 0833, }\end{array}$ \\
$\begin{array}{llcl}\text { Jan. 31, 1978 } \\
\text { pH }\end{array}$ & 6.00 & 6.12 & 4.14 \\
Density, $\mathrm{g} / \mathrm{cm}^{3}$ & 1.128 & 1.142 & 1.171 \\
Chloride, $M$ & 3.17 & 3.66 & 4.46 \\
Element & & & \\
\hline
\end{tabular}

\begin{tabular}{|c|c|c|c|}
\hline \multirow[b]{2}{*}{$\mathbf{L i}$} & \multicolumn{3}{|c|}{$\begin{array}{l}\text { Determined by atomic absorption } \\
\text { spectrophotometry, } \mathrm{mg} / \mathrm{kg}\end{array}$} \\
\hline & 110 & 124 & 142 \\
\hline $\mathrm{Na}$ & 44,000 & 51,000 & 57,000 \\
\hline $\mathbf{K}$ & 8,000 & 9,000 & 10,000 \\
\hline $\mathbf{R b}$ & 44 & 52 & 58 \\
\hline Cs & 10 & 11 & 11 \\
\hline $\mathbf{M g}$ & 78 & 72 & 84 \\
\hline $\mathrm{Ca}$ & 16,000 & 20,000 & 23,000 \\
\hline Sr & 392 & 341 & 418 \\
\hline $\mathbf{B a}$ & & $\sim 300^{a}$ & \\
\hline $\mathrm{Fe}$ & $134^{b}$ & $200^{b}$ & $233^{b}$ \\
\hline $\mathrm{Cu}$ & 0.7 & 0.9 & 0.8 \\
\hline $\mathbf{M n}$ & 453 & 596 & 680 \\
\hline $\mathbf{P b}$ & 37 & 61 & 61 \\
\hline $\mathbf{Z n}$ & 201 & 252 & 289 \\
\hline \multirow[t]{2}{*}{$\mathrm{Si}$ as $\mathrm{SiO}_{2}$} & 443 & 469 & 548 \\
\hline & ned by IC & ission spec & $\mathrm{try}, \mathrm{mg} / \mathrm{kg}$ \\
\hline Al & $<10$ & $<10$ & $<10$ \\
\hline As & 7 & 11 & 13 \\
\hline B & 405 & 440 & 512 \\
\hline Cd & 1.2 & 1.3 & 1.5 \\
\hline Co & 0.3 & 0.3 & 0.4 \\
\hline Mo & 4 & 4 & 5 \\
\hline $\mathbf{N i}$ & 0.2 & 0.2 & 0.4 \\
\hline $\mathbf{P}$ & 7 & 8 & 9 \\
\hline Ti & 0.4 & 0.4 & 0.4 \\
\hline $\mathbf{v}$ & 0.5 & 0.6 & 0.7 \\
\hline $\mathbf{Z r}$ & 0.3 & 0.3 & 0.3 \\
\hline
\end{tabular}

a See text.

betermined by visible spectrophotometry.

trations of barium in the vicinity of this value during the flash tank tests. This concentration is about twice that reported previously 11,12 for this brine, and thus many of the previous analyses may have been subject to the error of $\mathrm{BaSO}_{4}$ precipitation. The formation of this compound from these brines will be discussed further in connection with the analyses of the precipitated solids.

\section{FOUR-STAGE FLASH SYSTEM pH PROFILE}

During operation of the four-stage flash system with acidified brine, control of the brine $\mathrm{pH}$ was effected by manual measurement of discrete samples from various points in the system (Fig. 1). These samples were obtained through ambienttemperature cooling coils permanently installed in 
Table 7. Four-stage flash system pH profiles.

\begin{tabular}{|c|c|c|c|}
\hline \multirow[b]{2}{*}{ Sampling point } & \multicolumn{3}{|c|}{ pH } \\
\hline & $\begin{array}{l}\text { Unmodified } \\
\text { brine }^{\mathfrak{a}}\end{array}$ & $\begin{array}{c}\text { Target } \\
\mathbf{p H}=\mathbf{5}^{\mathbf{b}}\end{array}$ & $\begin{aligned} \text { Target } \\
\mathbf{p H}=\mathbf{3}^{\mathrm{c}}\end{aligned}$ \\
\hline First-stage separated brine & 6.14 & 6.12 & 6.00 \\
\hline $\begin{array}{l}\text { Separated brine downstream from } \\
\text { acid injection point }\end{array}$ & 6.10 & 4.36 & 2.94 \\
\hline Second-stage brine & 6.17 & 5.54 & 2.95 \\
\hline Second-stage steam condensate & 6.11 & 5.32 & 4.79 \\
\hline Third-stage brine & 6.09 & 5.41 & 2.90 \\
\hline Third-stage steam condensate & 6.50 & 5.68 & 3.52 \\
\hline Fourth-stage brine (control point) & 5.94 & 5.19 & 2.83 \\
\hline Output of delay line & 5.94 & 5.40 & 2.82 \\
\hline
\end{tabular}

asept. 20, 1978.

bept. 19, 1978.

'Sept. 18, 1978.

the system, and $\mathrm{pH}$ values were measured using laboratory $\mathrm{pH}$ meters. The brine at the fourth stage $\left(\sim 10^{\circ} \mathrm{C}\right)$ was designated as the control point, and the flow of acid was adjusted to achieve the desired $\mathrm{pH}$ at this point. This meant that other points in the system would deviate in $\mathrm{pH}$ from that at the control point. Thus it was of interest to learn the extent of these deviations. The $\mathrm{pH}$ of the fluids at several other points in the system were routinely monitored, and several times during the tests all accessible points were checked.

Typical results of the plant $\mathrm{pH}$ measurements are shown in Table 7. The $\mathrm{pH}$ values of the steam condensate fractions were always higher than those of the corresponding brines. This is characteristic of Niland brine flash systems and is due to the presence of ammonia in the condensate. The $\mathrm{pH}$ values might have been even higher were it not for the fact that the steam condensates are apparently contaminated by brine (see below). As was sometimes but not always the case, control of the $\mathrm{pH}$ at $\sim 5.2$ in this experiment (see Table 7) required the $\mathrm{pH}$ of the brine to be significantly lower at the point immediately downstream from where the acid was injected.

\section{STEAM CONDENSATE ANALYSES}

Several analyses of the steam condensates from the LLL four-stage flash system were carried out. The performance of the first-stage wellhead separator was very good, as indicated on two occasions by the purity of its steam condensate. Chloride concentrations were $10 \pm 1$ and $38 \pm 2$ $\mathrm{mg} / \mathrm{l}$ on October 23, 1977, and January 24,1978 , respectively. Sulfate concentrations at the same time were found to be 6 and $14 \mathrm{mg} / \mathrm{l}$; the presence of sulfate may have been due to the use of irrigation water as a purge liquid. The separator subsequently failed and was found to have accumulated large quantities of calcium sulfate scale. ${ }^{13}$ The concen- tration of sulfide in the first-stage steam condensate was measured by an ion-selective electrode technique on January 25,1978 , and found to be 43 $\mathrm{mg} / \mathrm{l}$. Because the GLEF was operating that day, this value can be regarded as a maximum value. At the same time, the concentration of sulfide in the condensate from the first stage of the GLEF was 33 $\mathrm{mg} / \mathrm{l}$.

Measurement of the steam condensate from the second and third stages of the LLL four-stage flash system yielded high values of chloride concentration: 3.00 and $3.50 M\left(\sim 10^{5} \mathrm{mg} / \mathrm{l}\right)$, respectively, on October 22, 1977. A change in sampling point 
did not chānge these values significantly. These concentrations were not greatly different from those of the brine at these stages of the system, and probably represented significant carryover of brine into the steam phase. It should be noted, however, that very little liquid brine is required in a large volume of steam to yield a steam condensate high in chloride. Moreover, the flash tanks themselves were not designed or expected to be efficient separators.

\section{ANALYSIS OF SUSPENDED SOLIDS}

The concentrations of suspended solids in the fluids of the four-stage flash system were determined in early experiments that have been discussed previously. ${ }^{6}$ The level of suspended solids in the effluent from the fourth stage was generally $\sim 50$ $\mathrm{mg} / \mathrm{kg}$ for unmodified brine and $<10 \mathrm{mg} / \mathrm{kg}$ for the acidified brines. No determinations of the upstream levels were carried out.

It was noted several times, when the $\mathrm{pH}$ of the brine was measured during the acidification experiments, that the separated, $200^{\circ} \mathrm{C}$ brine sampled downstream from the acid injection point contained high levels of black suspended solids. These tended to accumulate in the sample tubing, but could be flushed out by a high flow of the sampled brine. Because these particles might have been a cause of material erosion, they were collected and analyzed by $x$-ray fluorescence spectrometry. The major elements in these suspended solids were, in decreasing concentration, $\mathrm{Pb}, \mathrm{Fe}, \mathrm{Cu}, \mathrm{Ag}, \mathrm{As}, \mathrm{S}, \mathrm{Sb}$, and $\mathrm{Si}$; thus the solids appear to be predominantly silica and the sulfides of $\mathrm{Pb}, \mathrm{Fe}, \mathrm{Cu}, \mathrm{As}$, and $\mathrm{Sb}-$ the principal components of high-temperature scale.

\section{ANALYSIS OF PRECIPITATED SOLIDS}

During the course of the flash tank experiments, a large number of experiments were performed in which the effluent brine was sampled, sealed under nitrogen in glass ampoules, incubated at $90 \pm 5^{\circ} \mathrm{C}$, and analyzed to determine the rates of solids and silica precipitation. Baseline information on these rates in unmodified, diluted, and acidified brine was obtained, ${ }^{6}$ and the effects of organic additives on the solids and silica precipitation were later measured. ${ }^{3}$ In many cases, the solids formed were analyzed by $x$-ray fluorescence, $x$-ray diffraction, and emission spectrometry; these results are of interest here.

Table 8 lists several typical examples of the analyses of the solids precipitated from effluent Magmamax No. 1 brine. An examination of these and other data indicates a number of trends. First, the solids from the unacidified brine were nearly pure silica. Second, dilution ( $20 \%$ by weight) of the brine with pure, deaerated water changed the composition of the solids very little (but did delay silica precipitation and reduce the quantity of solids significantly 6 ). Third, acidification of the brine reduced the proportion of iron in the precipitate; this is reasonable since a lower pH would be expected to decrease the extent of hydrolysis of the iron species.

Probably the most important effect of acidification (note that the brine was acidified in the flash system, not in the laboratory) was that it dramatically increased the concentrations of barium, calcium, and strontium in the precipitated solids. X-ray diffraction analyses indicated that the barium occurred in the form of crystalline $\mathrm{BaSO}_{4}$ (barite) and that a large fraction of the calcium was found as $\mathrm{CaF}_{2}$ (fluorite). Both $\mathrm{BaSO}_{4}$ and $\mathrm{CaF}_{2}$ were also important constituents of the lowtemperature scales that formed from the acidified brines during the flash tank tests (see below).

Barium sulfate has often been found to be a major constituent of other geothermal 14,15 and oil-well fluid 16,17 scales, and its solubility has been studied as a function of temperature and salt concentration. ${ }^{18,19}$ A salient feature of the precipitation of $\mathrm{BaSO}_{4}$ is its tendency to form supersaturated solutions that are slow to reach equilibrium, 14,16-20 and thus exhibit delayed 
Table 8. Composition of solids precipitated from incubated effluent brine.a

\begin{tabular}{|c|c|c|c|c|}
\hline \multirow[b]{2}{*}{ Element } & \multicolumn{4}{|c|}{ Composition of precipitated solids, wt $\%$} \\
\hline & $\begin{array}{c}\text { Unmodified, } \\
\text { pH = 6.0; } \\
3.68 \mathrm{MCl}^{-}\end{array}$ & $\begin{array}{c}\text { Diluted } \\
\text { unmodified } \\
\text { brine }\end{array}$ & $\begin{array}{l}\text { Acidified, } \\
\text { pH = 3.8; } \\
4.27 \mathrm{MCl}^{-}\end{array}$ & $\begin{array}{l}\text { Acidified, } \\
\text { pH = 5.15; } \\
4.60 \mathrm{M} \mathrm{Cl}^{-}\end{array}$ \\
\hline $\mathrm{Si}$ as $\mathrm{SiO}_{2}$ & 96.9 & 94.3 & 85.6 & 68.7 \\
\hline $\mathbf{L i}$ & 0.001 & b & 0.001 & b \\
\hline $\mathbf{N a}$ & 0.1 & b & 0.03 & b \\
\hline $\mathbf{K}$ & 0.6 & 0.7 & trace & 0.2 \\
\hline $\mathbf{R b}$ & 0.002 & 0.002 & $<0.001$ & 0.002 \\
\hline Be & 0.0003 & b & 0.0001 & b \\
\hline $\mathbf{M g}$ & 0.003 & b & 0.002 & b \\
\hline $\mathrm{Ca}$ & 1.15 & 1.2 & $\mathbf{3 . 3}$ & 13.5 \\
\hline $\mathbf{S r}$ & 0.003 & 0.004 & 0.09 & 0.4 \\
\hline Ba & $<0.05$ & $<0.05$ & 4.2 & 10.4 \\
\hline B & 0.06 & b & 0.3 & b \\
\hline Al & 0.02 & b & 0.2 & b \\
\hline $\mathbf{s}$ & $<0.1$ & $<0.1$ & 0.4 & 1.9 \\
\hline As & 0.02 & 0.03 & 0.007 & 0.01 \\
\hline Sb & b & $\mathbf{b}$ & 0.004 & b \\
\hline $\mathbf{M n}$ & 0.08 & 0.14 & 0.002 & $<0.005$ \\
\hline $\mathrm{Fe}$ & 0.98 & 2.7 & 0.63 & 0.60 \\
\hline $\mathbf{A g}$ & 0.002 & b & 0.01 & b \\
\hline $\mathrm{Cu}$ & 0.016 & 0.12 & trace & 0.01 \\
\hline $\mathbf{Z n}$ & 0.17 & 0.21 & & 0.03 \\
\hline $\mathbf{P b}$ & 0.029 & 0.062 & 0.002 & 0.01 \\
\hline $\mathrm{Cl}^{-}$ & $<0.1$ & $<0.1$ & 0.28 & 4.0 \\
\hline
\end{tabular}

a Incubation for $7-9$ d at $90^{\circ} \mathrm{C}$.

bot determined.

precipitation. Solubility also increases with temperature and with salt concentration. 18,19

The conditions were not exactly the same as those encountered here, but from the data of Templeton ${ }^{18}$ for $4.0 \mathrm{M} \mathrm{NaCl}$ at $95^{\circ} \mathrm{C}$, the solubility product of $\mathrm{BaSO}_{4}$ was calculated to be $1.3 \times$ $10^{-7}$ (vs $1.0 \times 10^{-10}$ for pure water at $25^{\circ} \mathrm{C}$ ). Thus, at a $\mathrm{Ba}^{2}+$ concentration of $\sim 300 \mathrm{mg} / 1$, precipitation of $\mathrm{BaSO}_{4}$ should take place at a concentration of $\mathrm{SO}_{4}{ }^{2-}$ greater than $\sim 6 \mathrm{mg} / \mathrm{l}$. At the time this work was done, accurate prompt-sample analyses of the Magmamax No. 1 brine for sulfate did not exist, * but our value was the lower limit of the range of estimates for this and similar reducing

- Stability of the analytical sample is an important factor in the accuracy of the determination, but another problem is obtaining a truly representative sample of the well fluid that is not contaminated by ground water. brines in the Imperial Valley. ${ }^{12}$ Thus it appeared that solids precipitated from the Magmamax No. 1 brine probably should contain appreciable concentrations of $\mathrm{BaSO}_{4}$.

A possible source of sulfate in our tests was, as mentioned above, the use of irrigation water to purge the wellhead separator. However, $\mathrm{BaSO}_{4}$ was never found in the solids from effluent brine that had not been acidified nor from first-stage separated brine obtained upstream from the acidification point, even though these brines had been incubated for a sufficiently long time $(>1$ week) to reach equilibrium.

The most interesting question is why acidification of the brine markedly increased the concentrations of $\mathrm{BaSO}_{4}$ in the solids and probably also in the scales. Although we have not found $\mathrm{BaSO}_{4}$ in solids precipitated from unacidified brine at the 
LLL facility, it has been found at low concentrations $(\sim 2 \%)$ in scales formed from unacidified Magmamax No. 1 brine at the GLEF. ${ }^{21}$ It is known that the addition of acid to a supersaturated $\mathrm{BaSO}_{4}$ solution enhances the growth of large crystals in the precipitate 22 (and this may be a factor in our observations), but the long incubation times for the solids measurements should have eliminated the effects of different rates of crystal growth from the comparisons of acidified and unacidified brines.

It is also conceivable that additional sulfate ion was present during the acidification runs because of air oxidation of sulfide in the brine; the air could have been introduced in the $1.5 \mathrm{M}$ hydrochloric acid (ACS reagent grade) solution used for the on-line acidification. Unfortunately, the levels of sulfide in the brine have not been determined accurately; however, chemical model ${ }^{23}$ calculations (by D. D. Jackson, LLL) indicated that the concentrations of oxygen existing in the brine as a result of acidification were probably too low to oxidize sufficient quantities of sulfide ion. It appears that further speculation on the origin of the $\mathrm{BaSO}_{4}, \mathrm{CaF}_{2}$ (and possibly $\mathrm{SrSO}_{4}, \mathrm{CaSO}_{4}$ ) in the solids must await more complete measurements of the sulfate and fluoride anion concentrations in the brines and additional experiments with unacidified brine to deter- mine whether or not these compounds are represented in the long-term composition of Magmamax No. 1 fluids.

The element silver or its compounds have been found frequently to be minor constituents of the solids precipitated from the brine, and somewhat higher concentrations have been measured in scales formed at high temperature. In most of the routine $x$-ray and emission spectrographic analyses of precipitated solids, the concentration of silver appeared to be on the order of $0.01 \%$, but no careful assays of these solids for silver were done. To obtain a better indication of the typical concentration of precious metals in the precipitated solids and their value as minerals, a large sample of the acidified effluent brine (February 4, 1978; $4.7 M$ chloride; $1.175 \mathrm{~g} / \mathrm{cm}^{3}$ density) was taken, incubated in the usual manner at $90^{\circ} \mathrm{C}$ for 10 days, and filtered to recover the solids. The solids were then sent to a commercial laboratory that specialized in precious metal assay. The results were silver $(<0.001 \%)$, gold $(<0.005 \%)$, and platinum $(<0.01 \%)$; thus this particular sample had little monetary value. Because effluent brines originating from flash systems are much lower in sulfide ion than the hot upstream fluids, solids and scales formed from the latter should be much more promising sources of silver, especially as $\mathrm{Ag}_{2} \mathrm{~S}$.

\section{ANALYSIS OF SCALE SAMPLES}

After termination of the flash system operation, during which the test materials had been exposed to acidified brine, the four-stage flash system was disassembled and samples of scale were taken from various locations. A sample of scale was also obtained from the Magmamax No.1 wellhead.

The samples of scale taken from the wellhead, the first-stage separated-brine location, and the delay line had formed on relatively rapidly corroding mild-steel pipe. These samples therefore consisted of a mixture of both corrosion product and "true" scale, i.e., solid material that formed as a precipitate only from the constituents of the brine and then adhered to the surface of a substrate. Samples of scale from the other locations listed in Table 9 more nearly represented "true" scale because they were taken from coupons of Inconel 600 , which has been found to be one of the alloy materials most inert to the effects of acidified geothermal brine. ${ }^{7}$ The scales from these locations and the delay line formed from acidified brine; the wellhead and separated, $200^{\circ} \mathrm{C}$-brine scales formed from unmodified brine upstream from the point of acidification.

Before analysis, the samples of scale were crushed and mixed thoroughly in an attempt to obtain a bulk, cross-sectional composition of the material from the top of the scale deposit to the metal substrate. These scales typically varied in composition in cross section, ${ }^{1}$ but no attempt was made in the present study to define this. The scale samples also were analyzed in a nearly "as-is" condition, i.e., no attempt was made to remove entrained brine by water washing, and the samples were not heated to dry them beyond the condition reached in the ambient atmosphere. 
Table 9. Analyses of scale from Magmamax No. 1 wellhead and the LLL four-stage flash system after $\sim 720$ h operation.

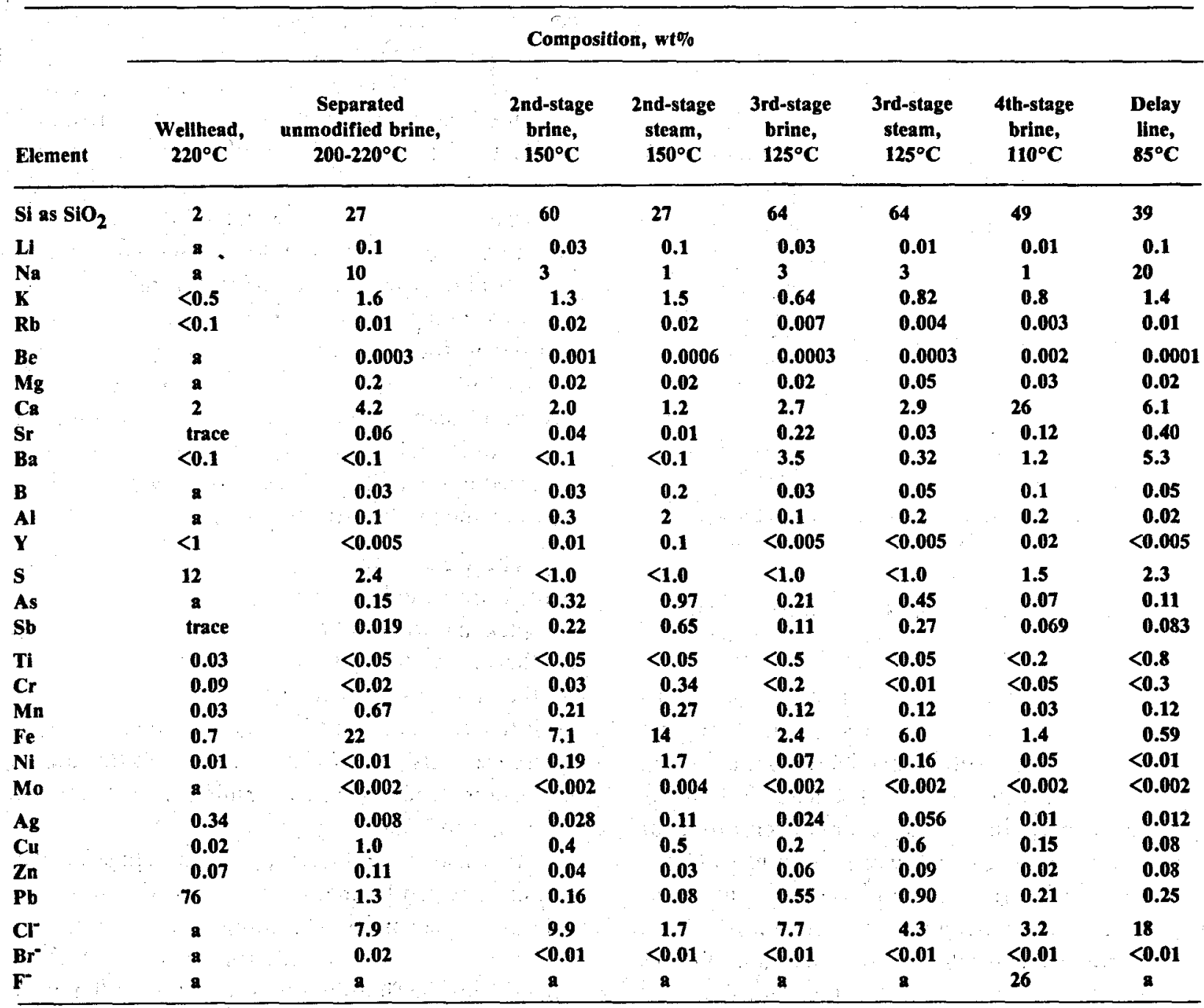

aNot determined.

A summary of the analyses of these scales by $\mathrm{x}$-fluorescence and emission spectrometry is given in Table 9. The scale samples were also examined by $x$-ray diffraction techniques, and these results are summarized in Table 10. Except for high concentrations of noncrystalline phases such as amorphous silica, this technique in general detects only crystalline phases, and only those greater than approximately $5 \%$ in concentration.

The elemental concentrations listed in Table 9 and the compound identification provided by $x$-ray diffraction revealed some interesting features of these scale samples. The wellhead sample appeared to be $\sim 88 \% \mathrm{PbS}, 4 \% \mathrm{SiO}_{2}$, and a few percent of unidentified iron and calcium compounds. Silver, probably as $\mathrm{Ag}_{2} \mathrm{~S}$ but possibly also as native silver, was present in an amount that made this material a valuable mineral.

The first-stage separated-brine scale, although formed at high temperature $\left(200-220^{\circ} \mathrm{C}\right)$, appeared to contain $\sim 27 \% \mathrm{SiO}_{2}$ and probably an equal amount of entrained $\mathrm{NaCl}$. Although we have expressed the concentrations of silicon as $\mathrm{SiO}_{2}$, we cannot rule out the possible presence of many metal silicate compounds as well. The only one actually identified was montmorillonite, a complex aluminum silicate (Table 10). The particular compound or compounds that yielded the high $(22 \%)$ concentration of iron in this sample (or in the other scale samples as well) were not identified. In this 
Table 10. Principal phases in scales from LLL fourstage flash system identified by $x$-ray diffraction.

\begin{tabular}{|c|c|c|}
\hline Stage & Major phases & Minor phases \\
\hline Wellhead & galena-PbS & amorphous silica-SiO \\
\hline $\begin{array}{l}\text { 1st-stage } \\
\text { separated brine }\end{array}$ & $\begin{array}{l}\text { amorphous silica-SiO, } \\
\text { halite-NaCl }\end{array}$ & $\begin{array}{l}\text { calcite }-\mathrm{CaCO}_{3} \\
\text { galena-PbS } \\
\text { montmorillonite clay }\end{array}$ \\
\hline 2nd-stage brine & amorphous silica-SiO & $\begin{array}{l}\text { halite }-\mathrm{NaCl} \\
\text { sylvite }-\mathrm{KCl} \\
\text { montmorillonite clay }\end{array}$ \\
\hline 2nd-stage steam & amorphous silica-SiO 2 & halite - $\mathrm{NaCl}$ \\
\hline 3rd-stage brine & amorphous silica - $\mathrm{SiO}_{2}$ & $\begin{array}{l}\text { halite }-\mathrm{NaCl} \\
\text { fluorite }-\mathrm{CaF}_{2} \\
\text { barite }-\mathrm{BaSO}_{4}\end{array}$ \\
\hline 3rd-stage steam & amorphous silica-SiO 2 & $\begin{array}{l}\text { halite }-\mathrm{NaCl} \\
\text { fuorite }-\mathrm{CaF}_{2} \\
\text { sylvite }-\mathrm{KCl}\end{array}$ \\
\hline 4th-stage brine & $\begin{array}{l}\text { amorphous silica-SiO } \\
\text { fluorite }-\mathrm{CaF}_{2}\end{array}$ & $\begin{array}{l}\text { barite }-\mathrm{BaSO}_{4} \\
\text { halite }-\mathrm{NaCl}\end{array}$ \\
\hline Delay line & $\begin{array}{l}\text { halite }-\mathrm{NaCl} \\
\text { amorphous silica-SiO }\end{array}$ & $\begin{array}{l}\text { fluorite - } \mathrm{CaF}_{2} \\
\text { barite }-\mathrm{BaSO}_{4} \\
\text { sylvite }-\mathrm{KCl}\end{array}$ \\
\hline
\end{tabular}

sample, the iron may have arisen chiefly as a product of the corrosion of the pipe steel substrate, and many compounds were possible. It is interesting that this scale also contained calcite and montmorillonite clay, the former at a concentration of $5-10 \%$ if all of the calcium was present as $\mathrm{CaCO}_{3}$.

The scales formed from the second- and thirdstage brines appeared to be nearly two-thirds silica. Again, some metal silicates such as iron silicates also may have been present, but the elemental concentrations and the nonsilicaceous compounds identified indicated that, as in many previous studies, ${ }^{1}$ the dominant substance was amorphous silica. The third-stage brine scales and those formed downstream also exhibited significant concentrations of $\mathrm{BaSO}_{4}$ and $\mathrm{CaF}_{2}$ that, as discussed above, were also characteristic of the solids precipitated homogeneously from the system effluent brine. It may be more than a coincidence that these compounds first appeared at the point where the rate of growth of scale was a maximum.

The concentration of $\mathrm{CaF}_{2}$ in scale formed at the fourth stage was strikingly high. Because of the high concentration of calcium and the evidence for $\mathrm{CaF}_{2}$ obtained by $\mathrm{x}$-ray diffraction, an additional analysis specifically for $\mathrm{CaF}_{2}$ was carried out. A spectrographic method based on the observation of $\mathrm{CaF}$ molecular bands was used, and calibration was based on National Bureau of Standards phosphate rock $(3.92 \% \mathrm{~F})$, opal glass $(5.72 \% \mathrm{~F})$, and pure $\mathrm{CaF}_{2}(48.7 \% \mathrm{~F})$. On the basis of this analysis, it was estimated that the concentration of $\mathrm{CaF}_{2}$ in the scale from the fourth stage was $\mathbf{4 0 \%}$.

The scale found in the delay line apparently contained large amounts $(\sim 50 \%)$ of entrained $\mathrm{NaC1}$. It also contained the highest concentration $(\sim 9 \%)$ of $\mathrm{BaSO}_{4}$ and $10 \% \mathrm{CaF}_{2}$. A large portion of this scale might have been water soluble. The principal phases found in these low-temperature scales were also identified on the surfaces of mild steel exposed for much shorter periods of time to acidified brine ${ }^{24}$; in those experiments, however, corrosion of the substrate also produced thin layers of elemental lead, $\mathrm{PbCO}_{3}$, and copper-containing compounds. These compounds were evidently obscured in the bulk analysis of the thick long-term scales of the present study.

The trends in composition of the scales with temperature and location in the system illustrate the complex nature of the scaling processes in these geothermal systems. Because of the differing rates of the important reactions causing precipitation, both temperature and the "age" of the brine (with reference to its time of flow from the wellhead) are important variables in determining the distribution of compounds in the scales.

It is also apparent that approaches to scale control in these geothermal systems must take into consideration the variety of compounds that constitute the scales. A scale inhibitor that is effective throughout the fluid-handling structure will have to control metal-sulfide scales at high temperatures, amorphous silica (or silicates) at intermediate and low temperatures, and the crystalline phases such as $\mathrm{BaSO}_{4}$ and $\mathrm{CaF}_{2}$ at low temperatures. Moreover, agents that reduce the formation of these scale compounds would increase the exposure of the metal surfaces and hence their susceptibility to corrosion. Thus brine treatment to control scaling may also require special materials of construction or corrosion inhibitors. The ideal chemical additive for the control of scale and the protection of plant materials might be a mixture of compounds, each tailored to a specific task. On the other hand, it has long been believed 25,26 that scales deposited from brines of the Salton Sea geothermal field are always formed on a silica substrate or in a silica matrix; thus it is possible that control of only a single compound, silica, will be the key to scale control in general. 
The analytical results and interpretations reported here reveal several areas for future work that could enhance our understanding of the chemistry of these hypersaline brine systems. Although difficult in each case, more accurate and frequent measurements of the concentration of the scale-forming anions-sulfide, sulfate, and fluoride-in the brine would be useful. A more detailed analysis of the scale and solids by techniques such as infrared spectroscopy, Raman spectroscopy, selective solvent leaching, microscopy, or even photoelectron spectroscopy might pinpoint their composition more precisely.

\section{EFFECT OF ACIDIFICATION ON SCALING RATES}

During most of the period of operation of the flash system, the brine was acidified by injection of hydrochloric acid. This afforded some comparisons of the acidified-brine scaling rates with those found for untreated brine. The flash system was operated for a total of $1042 \mathrm{~h}$ : $115 \mathrm{~h}$ without acid ( $\mathrm{pH}$ of 26.0) followed by $927 \mathrm{~h}$ with acid injection ( $\mathrm{pH}$ of 4 to 5). Thicknesses of scale were measured by sectioning portions of the brine drain lines between stages. A summary of these observations is given in Table 11.

Comparison of the results for the $210^{\circ} \mathrm{C}$ line before and after acidification shows that the reduction in scaling rate due to the lowered $\mathrm{pH}$ was dramatic-a factor of about 21. An indication of the improvement in the scaling rates at the lower temperatures is possible by comparing the acidifiedbrine rates found here with rates for unmodified brine measured at the GLEF. The apparent decreases in scaling rates are factors of $\sim 7.5,2.6$ and 8.3 at temperatures of 150,125 , and $105^{\circ} \mathrm{C}$, respectively. The lesser improvement at $125^{\circ} \mathrm{C}$ may have been due partly to the fact that, as shown below, the scales formed at this and lower temperatures begin to contain increasing amounts of $\mathrm{BaSO}_{4}$ and $\mathrm{CaF}_{2}$. The precipitation of these substances, unlike that of $\mathrm{SiO}_{2}$, is not inhibited by the lowered $\mathrm{pH}$. Another possible explanation for the peak in scaling rate at $125^{\circ} \mathrm{C}$ is that two effects tend to work in opposite directions. One is the degree in silica supersaturation, which increases as the temperature is lowered; the second is the rate of silica polymerization (or precipitation), which decreases (for a given degree of supersaturation) as the temperature is lowered. Thus the net rate of precipitation, or scaling, may reach a maximum at an intermediate temperature. Acid consumption and costs were found to be consistent with those reported previously for nozzle expansion tests. 1

Corrosion rates of carbon and low-alloy steels were generally increased 2,7 by acidification of the

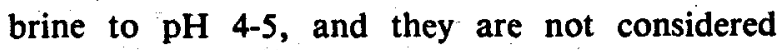

Table 11. Rates of scale formation in brine drain lines of LLL four-stage flash system.

\begin{tabular}{|c|c|c|c|c|c|}
\hline Location & $\begin{array}{c}\text { Scale } \\
\text { thickness, mil }\end{array}$ & $\begin{array}{c}\text { Time of } \\
\text { exposure, } h\end{array}$ & $\begin{array}{l}\text { Indicated } \\
\text { scaling } \\
\text { rate, mil/h }\end{array}$ & $\begin{array}{l}\text { Scaling rate } \\
\text { at GLEF, } \\
\mathrm{mil} / \mathrm{h}\end{array}$ & $\begin{array}{l}\text { Scaling- } \\
\text { reduction } \\
\text { factor }^{2}\end{array}$ \\
\hline $\begin{array}{r}\text { 1st-stage drain, } 210^{\circ} \mathrm{C} \\
\text { (before acidification) }\end{array}$ & 219 & 1042 & 0.21 & & \\
\hline $\begin{array}{l}\text { 1st-stage drain, } 210^{\circ} \mathrm{C} \\
\text { (after acidification) }\end{array}$ & 31 & $1042^{b}$ & 0.01 & & 21 \\
\hline 2nd-stage drain, $150^{\circ} \mathrm{C}$ & 144 & $1042^{b}$ & 0.08 & 0.6 & 7.5 \\
\hline 3rd-stage drain, $125^{\circ} \mathrm{C}$ & 187 & $532^{c}$ & 0.35 & 0.9 & 2.6 \\
\hline 4th-stage drain, $105^{\circ} \mathrm{C}$ & 65 & $532^{c}$ & 0.12 & 1.0 & 8.3 \\
\hline
\end{tabular}

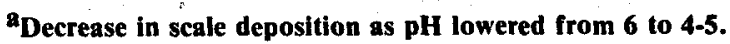

b 115 h without acid; scaling rate calculated for acid period only.

$c_{2}$ h without acid; line cleaned before 532-h test period. 
suitable as materials of construction for acidified brine service. Several materials suitable for application as liners on carbon steel vessels and piping were virtually unaffected after 927 hours exposure to brine at $\mathrm{pH}$ 4-5. These include Hastelloy C-276, Inconel 600 , and $29-4(29 \% \mathrm{Cr}, 4 \% \mathrm{Mo}$, and $67 \%$ $\mathrm{Fe})$. A complete report on the corrosion behavior of a wide variety of materials exposed to acidified brine will be published as a companion paper ${ }^{7}$.

We are currently investigating other methods of scale control which do not involve reduction in $\mathrm{pH}$, e.g.; addition of organic polymers ${ }^{3}$ and sludge recycle. Such methods, if successful, may permit plant construction using the usual carbon steels.

\section{ACKNOWLEDGMENTS}

Many persons participated in the work reported here. Chemical analyses were performed by C. O. Pruneda, C. J. Morris, and R. Lim (solution chemistry); W. J. Beiriger (x-ray diffraction); R. G. Gutmacher, E. S. Peck, and B. Armstrong (emission spectroscopy); and D. R. McKenzie (x-ray fluorescence). The statistical analysis of the brine data was done by J. Magistad. Discussions of the results with R. D. McCright, R. Quong, L. B. Owen, J. H. Hill, and D. D. Jackson have been very valuable. 


\section{REFERENCES}

1. A.L. Austin, A.W. Lundberg, L.B. Owen, and G.E. Tardiff, Eds., The LLL Geothermal Energy Program Status Report, January 1976-January 1977, Lawrence Livermore Laboratory, Livermore, Calif., UCRL-50046-76 (1977).

2. R.D. McCright, R.E. Garrison, and F.E. Locke, "Corrosion Testing in a Multiple-Stage Flash System," in Transactions of the Geothermal Resources Council Meeting, 1978 (Geothermal Resources Council, Davis, 1978), vol. 2, pp. 415-418.

3. J.E. Harrar, L.E. Lorensen, C.H. Otto, Jr., S.B. Deutscher, and G.E. Tardiff, "Effects of Organic Additives on the Formation of Solids from Hypersaline Geothermal Brine," in Transactions of the Geothermal Resources Council Meeting, 1978 (Geothermal Resources Council, Davis, 1978) vol. 2, pp. 259-262.

4. R. Netherton and L.B. Owen, "Apparatus for the Field Evaluation of Geothermal Effluent Injection," in Transactions of the Geothermal Resources Council Meeting, 1978 (Geothermal Resources Council, Davis, 1978), vol. 2, pp. 487-490.

5. J.D. Tewhey, M.A. Chan, P.W. Kasameyer, and L.B. Owen, "Development of Injection Criteria for Geothermal Resources," in Transactions of the Geothermal Resources Council Meeting, 1978 (Geothermal Resources Council, Davis, 1978), vol. 2, pp. 649-652.

6. J.E. Harrar, C.H. Otto, Jr., J.H. Hill, C.J. Morris, R. Lim and S.B. Deutscher, Determination of the Rate of Formation of Solids from Hypersaline Geothermal Brine as a Function of pH, Lawrence Livermore Laboratory, Livermore, Calif., UCID-17596 (1978).

7. R.D. McCright, R.E. Garrison, and J.E. Harrar, Corrosion Resistance of Metals in Hypersaline Geothermal Environments: Electrochemical and Weight Loss Determinations, presented at meeting of Metallurgical Society of AIME, New Orleans, February 1979.

8. A.C. Makrides, M.J. Turner, W.W. Harvey, J. Slaughter, S.B. Brummer, P.O'D. Offenhartz, and G.F. Pearson, Study of Silica Scaling from Geothermal Brines, EIC Corporation and U.S. Department of Energy Rept. COO-2607-5 (1978).

9. A.J. Ellis and W.A.J. Mahon, Chemistry and Geothermal Systems (Academic Press, New York, 1977), pp. 145-148.

10. J.E. Harrar, Ed., General Chemistry Division Quarterly Report, April through June, 1978, Lawrence Livermore Laboratory, Livermore, Calif., UCID-15644-78-2 (1978), p. 37.

11. Ref. 1, pp. 88-89.

12. T.D. Palmer, Characteristics of Geothermal Wells Located in the Salton Sea Geothermal Field, Imperial County, California, Lawrence Livermore Laboratory, Rept. UCRL-51976 (1975).

13. L.B. Owen and G.E. Tardiff, Eds., LLL Geothermal Energy Development Program Highlights Report, September, 1978, Lawrence Livermore Laboratory, ATHS/ISP-17, pp. 89-96.

14. O.J. Vetter, J. Pet. Technol. 27, 1515 (1975).

15. T.E. Lindemuth, E.H. Houle, S.H. Suemoto, and V.C. Van der Mast, "Experience in Scale Control with East Mesa Geothermal Brine," Proceedings of Int. Symp. on Oilfield and Goethermal Chemistry, Society of Petroleum Engineers, San Diego, 1977, pp. 173-186.

16. O.J. Vetter, J. Pet. Technol. 28, 1402 (1976).

17. D.J. Weintritt and J.C. Cowan, J. Pet Technol. 19, 1381 (1967).

18. C.C. Templeton, J. Chem. Eng. Data 5, 514 (1960).

19. J.W. Davies and A.G. Collins, Environ. Sci. Technol. S, 1039 (1971).

20. G.H. Nancollas and N. Purdie, Trans. Far. Soc. 59, 735 (1963).

21. H.K. Bishop, San Diego Gas and Electric Co., private communication (May 1978).

22. I.M. Kolthoff and E.B. Sandell, Textbook of Quantitative Chemical Analysis, 3rd Ed. (Macmillan, New York, 1952), p. 323.

23. Ref. 1, p. 100.

24. J.E. Harrar, J.W. Fischer, W.J. Beiriger, W.J. Steele, S.A. Digiallonardo, and D.D. McCoy, Incipient Processes in the Corrosion of Mild Steel in $90^{\circ} \mathrm{C}$ Hypersaline Geothermal Brine, Lawrence Livermore Laboratory, Preprint UCRL-81606 (1978).

25. Ref. 1, p. 59.

26. L.B. Owen, Lawrence Livermore Laboratory, private communication (October 1978). 